\title{
HOMICÍDIOS NA BAIXADA FLUMINENSE: ESTADO, MERCADO, CRIMINALIDADE E PODER ${ }^{1}$
}

\author{
HOMICIDES IN THE BAIXADA FLUMINENSE: STATE, MARKET, CRIME AND POWER
}

\author{
André Rodrigues ${ }^{1}$ \\ ${ }^{1}$ Universidade Federal Fluminense (UFF), Rio de Janeiro, RJ, Brasil \\ Correspondência para: André Rodrigues (arodrigues@iser.org.br) \\ doi: 10.12957/geouerj.2017.32058 \\ Recebido em: 1 nov. 2017 | Aceito em: 12 dez. 2017
}

\section{RESUMO}

Este artigo tem por finalidade abordar dinâmicas recentes dos homicídios na Baixada Fluminense, em articulação com fatores de longa duração e estruturais na história dessa região. A metodologia empregada na análise conjuga, assim, a leitura de interpretações históricas sobre a formação política da região e uma pesquisa qualitativa realizada ao longo de ano de 2016. Pretendemos mostrar as relações entre os modos de atuação dos principais grupos criminosos que atuam na Baixada e os homicídios. Um aspecto importante da análise proposta é o modo pelo qual a violência letal é empregada como fator de base para a operação de mercados ilegais dos quais participam, em escala considerável, agentes do Estado, tanto policiais quanto parlamentares e membros do Judiciário. Essa rede criminosa que se organiza em torno dos homicídios consiste no que chamamos aqui de clientelismo homicida.

Palavras-chave: homicídios, Baixada Fluminense, violência, política, clientelismo.

\section{ABSTRACT}

This article aims to address recent dynamics of homicides in the Baixada Fluminense, in articulation with long-term and structural factors in the history of this region. The methodology used in the analysis combines historical interpretations about the political formation of the region and a qualitative research carried out throughout 2016. We intend to show the relations between the modes of action of the main criminal groups that operate in the Baixada and the homicides. An important aspect of the proposed analysis is the way in which lethal violence is used as the basis for the operation of illegal markets in which State agents, both policemen, parliamentary, and members of the Judiciary, participate on a considerable scale. This criminal network organized around homicides consists of what we call homicidal patronage.

Keywords: homicides, Baixada Fluminense, violence, politics, patronage.

Eu acredito que a violência é uma indústria lucrativa no Brasil.

(Ativista da Baixada Fluminense)

\section{INTRODUÇÃO: “Ali era uma casa de família!”}

A Baixada Fluminense, desde a primeira metade do século passado, figura no imaginário nacional (talvez mesmo internacional) como região caracterizada pelo alto índice de incidências criminais

\footnotetext{
${ }^{1}$ Este trabalho é resultado da pesquisa que coordenei pelo ISER no ano de 2016. Atuaram na pesquisa: Raquel Guilherme e Elizabete Albernaz, como supervisoras de campo, Juliana Águida, Leandro Marinho e Cássia Carvalho como pesquisadores de campo, Francyne Motta, Betânia Almeida e Carolina de Souza Costa, como estagiárias.
} 
violentas, pela articulação entre grupos criminosos organizados e segmentos da sociedade formal (comerciantes, empresários, etc.) e por uma forte influência do crime na política local. A região integra a metrópole do Rio de Janeiro e, de acordo com os limites reconhecidos pela administração pública fluminense, reúne treze municípios ${ }^{2}$. A Baixada passou por diversos ciclos econômicos que foram determinantes para constituição das municipalidades que a compõem; desde o escoamento da produção agrícola do interior do estado, no final do Império e início da República Velha, por sua rede fluvial cuja foz se dirige para a Baía de Guanabara, até o vertiginoso crescimento populacional da metrópole, nas últimas décadas, com o desenvolvimento do setor de serviços local e com concentração de imensa massa populacional que serve de mão-de-obra para a capital. Houve ainda, nesse processo de mais de um século, um movimento de declínio das antigas propriedades rurais da região, seguido de uma “onda loteadora" ${ }^{3}$ na qual as propriedades foram repartidas em porções menores de terra e vendidas, passando ainda por um curto período em que a agricultura volta a crescer em torno da produção de laranja. Em torno da metade do século XX, com seu declínio econômico, os municípios da Baixada se tornaram cidades dormitórios, com uma parcela expressiva de sua população orbitando em atividades produtivas na capital fluminense.

Em contraste com a muito variável e atribulada história da Baixada, dois eixos parecem possuir certa permanência: o nexo entre a constituição dos poderes políticos locais e o uso de métodos violentos, como os assassinatos; e a condição periférica em relação à cidade do Rio de Janeiro. Esses dois aspectos das circunstâncias políticas, econômicas e sociais da região, como procuraremos mostrar ao longo deste estudo, são fundamentais para a compreensão de como se engendram as lógicas criminosas que fazem da Baixada uma das regiões mais violentas do estado, apresentando um patamar quase que constante de alta letalidade violenta, há décadas.

\footnotetext{
${ }^{2}$ Belford Roxo, Duque de Caxias, Guapimirim, Itaguaí, Japeri, Magé, Mesquita, Nilópolis, Nova Iguaçu, Paracambi, Queimados, Seropédica e São João de Meriti. José Claudio Souza Alves (2003), ao debater os limites da região, mostra que há muitas outras possibilidades de descrever geograficamente aonde começa e termina a Baixada. Por razões de simplificação analítica, consideraremos o perímetro reconhecido nos padrões da administração pública.

${ }^{3}$ A expressão é de Alves (Idem). Para maiores aprofundamentos da historia econômica, social e política da Baixada, essa obra é fundamental e dela nos servimos para essa caracterização inicial da região.
} 
A tônica da do desenvolvimento da região, em situação periférica da Baixada em relação à capital, é ditada por um processo que ocorre sempre a reboque das dinâmicas da cidade do Rio de Janeiro. Hélio R. S. Silva (2012), ao analisar as assimetrias da metrópole do Rio de Janeiro a partir da história de nossas linhas ferroviárias, mostra, por exemplo, que todas as linhas dirigidas para a Baixada tinham por finalidade primeira em seu surgimento o abastecimento da capital e não o transporte dos moradores da região.

No que se refere às vinculações entre a política local e a violência letal, a Baixada apresenta uma longa história na qual o uso de expedientes violentos de poder foi uma das principais fontes de capital político para alçar lideranças locais aos cargos eletivos formais. O controle dos territórios por barões, coronéis, mandões, chefetes ou lideranças que atuam a partir de uma mescla de brutalidade e relações de clientela foi e ainda é uma fonte importante do poder local na Baixada. Ser "dono" de uma área, nessa gramática do poder, significa ter o controle dos ganhos econômicos decorrentes desse domínio, através do monopólio sobre o fornecimento de certos serviços, muitos deles de responsabilidade pública, como a oferta de água, transportes ou a garantia da segurança. Mas possuir esse tipo de poder vai além: 0 “dono” da área controla também um quantitativo de eleitores. Foi assim no passado. É assim no presente.

No passado, a atuação de matadores e grupos de extermínio fez emergir personagens que, pela atualização da herança coronelista que ainda encontrava ressonâncias depois do Estado Novo, tiveram grande proeminência local, chegando a figurar no cenário político nacional. É o caso de Tenório Cavalcanti, o Homem da Capa Preta. Ele emerge no cenário da Baixada, especificamente em Caxias, a partir de seus vínculos pessoas com político influentes na região. Chegado de Alagoas em 1926 e pertencente a uma família poderosa naquele estado, Tenório Cavalcanti é acolhido pelo deputado Natalício Camboim de Vasconcelos, seu tio e padrinho. Torna-se, então, próximo de Hildebrando de Góes, que dirigia o Departamento de Portos, Rios e Canais, órgão público que administrava àquela altura o saneamento básico da Baixada. A partir de sua atuação na gestão pública, ele passa a ter acesso ao negócio da venda de carvão e lenha - microeconomia muito característica da Baixada naquele período como um subproduto do loteamento predatório das antigas propriedades rurais. 
Tenório Cavalcanti, em vista dos ganhos econômicos decorrentes dessas atividades, chega a possuir 43 propriedades na região. A violência como marca de sua atuação foi resultado justamente do papel que desempenhou nos conflitos pela terra, tendo em vista que, nesse período, a Baixada vivenciava constantes confrontos entre jagunços pela definição da posse das terras ${ }^{4}$. 0 seu desempenho nessas relações violentas de poder fez a fama e a cama: vereador, deputado estadual e deputado federal, foram alguns dos cargos que o Homem da Capa Preta ocupou ao longo de sua trajetória política. Sempre munido de sua metralhadora apelidada de Lurdinha, arma que nunca deixou de portar mesmo ao frequentar as arenas públicas desde as casas legislativas locais ao Congresso Nacional. O porte dessa arma durante o exercício de suas atividades de parlamentar e de gestor do executivo municipal é, aliás, uma espécie de síntese simbólica da natureza do poder político que o levou à carreira pública. Uma trajetória marcada pela violência que fez com que ele acumulasse, entre 1928 e 1953, 47 ferimentos de bala e 8 prisões ${ }^{5}$.

O contexto atual da Baixada, obviamente, é muito distinto daquele dos tempos de Tenório Cavalcanti. Mas a figura da liderança que emerge através do uso do poder armado e cuja influência ascende do local para o municipal, do municipal para o estadual e do estadual para o nível federal parece ser um modelo ainda presente na Baixada, como tentaremos mostrar.

O coronelismo teve como característica fundamental a constituição de uma lógica do poder na qual as esferas estadual e federal se alimentavam do poder dos coronéis nos contextos municipais. O poder dos coronéis garantia os redutos eleitorais locais que interferiam na vitória ou derrota dos candidatos aos cargos estaduais e federais ${ }^{6}$. Como define José Murilo de Carvalho (1997), esse foi um sistema político restrito ao contexto da República Velha. Esse sistema trazia no seu bojo, entretanto, práticas políticas que perduraram do Estado Novo aos dias atuais de nossa recente democracia, tais como o mandonismo e o clientelismo. O mandonismo consiste na atuação de um chefete local que controla determinado território, utilizando-se muitas vezes de meios violentos de poder. O clientelismo, por sua vez, consiste na adoção de uma prática de favorecimentos privados como elemento fundamental do poder local.

\footnotetext{
${ }^{4}$ Para uma descrição detalhada desse processo, ver Alves (Idem, pp. 82-83).

${ }^{5}$ Ibid. p. 84.

${ }^{6}$ Ver Leal (1980)
} 
Tanto o mandonismo quanto o clientelismo são recursos para a produção de poder político que em muitos contextos brasileiros ainda estão em voga.

A equação política característica da Baixada, por sua vez, é a seguinte: o controle armado do território resulta na obtenção de ganhos econômicos e no controle de votos; a obtenção de um reduto eleitoral resulta na capitalização de poder na esfera municipal, sobretudo, legislativa. Há, porém, um traço desse padrão de poder que as noções de mandonismo ou clientelismo não dão conta isoladamente: 0 poder de matar como fonte primária de autoridade. Tanto Victor Nunes Leal, ao tratar do coronelismo, quanto José Murilo de Carvalho, nos reparos terminológicos que fornece a esse conceito ao delimitar mais estritamente seu alcance e suas distinções com as noções de mandonismo e clientelismo, não privilegiam essa dimensão em suas análises. Eles enfatizam, em vez disso, o modo pelo qual os poderes locais, a partir de apropriações privadas, se vinculam com a constituição de esferas mais ampliadas. Os propósitos das argumentações desses autores, obviamente, são muito distintos das preocupações que permeiam o presente estudo. Isso requer justamente novas ênfases para os aspectos que constituem essas categorias políticas e o modo como podem operar para a interpretação do contexto aqui analisado.

O poder de matar era, certamente, um recurso importante e disponível para o coronel da República Velha, bem como o é para os chefetes e mandões contemporâneos. $\mathrm{O}$ assassinato figura, entretanto, como um recurso residual para os poderes passíveis de serem descritos pelas categorias de mandonismo ou clientelismo: fazer morrer, nas versões mais convencionais, parece um recurso extremo na falha das formas menos violentas de controle - como as relações pessoais e econômicas. Ao menos essa é a impressão transmitida na leitura da composição conceitual operada na literatura. No contexto empírico da Baixada, porém, o uso da força indica que o assassinato não é um recurso residual ou extremo da constituição dos poderes locais que se estruturam na fronteira entre o legal e o ilegal. Pelo contrário. Matar é uma ferramenta ordinária e primária de poder. Poder matar é ter poder na Baixada Fluminense. Ou, invertendo a construção para reforçar o ponto: ter poder político na Baixada passa pela franquia ao direito de matar. 
Atenhamo-nos a dois fatores que permeiam os vínculos entre o poder político e os homicídios: o caráter cotidiano e frequentemente impessoal - meramente quantitativo - das execuções; e o modo pelo qual essas dinâmicas homicidas compõem os repertórios da atuação dos grupos criminosos mais diretamente vinculados à política municipal, como as milícias e os grupos de extermínio. 0 modo pelo qual esses grupos consolidam seu controle territorial está diretamente relacionado com seu cotidiano homicida. Seja no fornecimento de segurança privada, seja nas sanções aos descumprimentos das regras que ditam nas áreas que controlam, ou ainda no que se refere à mera demonstração de força, poder matar é a principal moeda política desses grupos. Os grupos de extermínio, por exemplo, se consolidaram como forças locais pelo exercício do assassinato como ferramenta de poder. As milícias, da mesma forma, operam o poder de matar como o elemento que estabelece seu controle local. No padrão originário das organizações criminosas, os assassinatos em praça pública, com finalidades expiatórias, eram um recurso para a afirmação do poder local. Esse padrão homicida mais ostensivo, como indicam Cano e Duarte (2012), foi substituído por execuções mais discretas e silenciosas, mas nada indica que as mortes cometidas pelas milícias tenham se tornado menos corriqueiras. É recorrente, nos modos de consolidação de poder desses grupos, a perpetração de execuções cujas vítimas não possuem nenhuma relação com seus executores: não descumpriram nenhuma ordem, ou regra, nem cometeram nenhum “delito”, por exemplo. Esse é o caso das chacinas, tão emblemáticas e frequentes na Baixada. Nessas execuções, os assassinos atiram a esmo contra moradores de determinados bairros. Mesmo quando não se tratam de chacinas, ao que parece, a aquisição de poder depende dos assassinatos como um recurso primordial, em combinação com os arranjos econômicos e as relações de lealdade. A quantidade das mortes se converte em certo quantum de poder local. $\mathrm{O}$ assassinato opera, portanto, como uma espécie de commodity politica, fazendo girar uma economia politica dos assassinatos. Esse contexto, no qual o homicídio é um recurso primário de poder, nos leva a descrever o nexo entre os homicídios e a política na Baixada como um clientelismo homicida, ou seja, uma forma de controle territorial que visa produzir uma rede de favores privados para a apropriação da coisa pública, mas que tem o assassinato como o seu recurso primário e imediato de poder.

As consequências desse padrão homicida para a coisa pública se encontram na esteira das caracterizações que Hannah Arendt descreve a respeito da violência como ação muda, corrosiva dos 
sentidos da experiência coletiva, logo, da política. Mas se considerarmos os assassinatos em questão somente por seu caráter de destruição de sentidos, corremos o risco de deixar de lado os significados brutais e específicos engendrados por essas configurações específicas de poder. No que concerne a essa preocupação, talvez seja mais produtiva uma abordagem que interprete o fazer morrer como fenômeno social. Em seu vasto volume sobre uma antropologia da morte, Louis-Vincent Thomas (1983) dedica um capítulo à morte matada, ou ao fazer morrer, como ele define. Nesse capítulo, Thomas descreve uma série de atos de fazer morrer que possuem significados sociais específicos em diferentes culturas. Desde a guerra, passando pela pena de morte, pelo parricídio, pelo genocídio, pelo regicídio etc., Thomas mostra que o fazer morrer pode possuir, a depender dos contextos sociais, um caráter constitutivo de padrões sociais, morais ou institucionais específicos. Em vista disso, ele distingue o homicídio dessas outras formas de fazer morrer. Ele restringe, dessa forma, os homicídios aos assassinatos de natureza mais particular, eventual e circunstanciada, definindo seis tipos: por prazer, por impulso, por preconceitos, por vingança, por covardia e por desequilíbrio. Nós, analistas da criminalidade e da violência, tendemos a reproduzir a nomenclatura jurídico-criminológica para descrevermos eventos e contextos que esse léxico não alcança. Acabamos, com isso, de chamar de homicídio um conjunto muito amplo de fenômenos muito distintos entre si. Talvez devêssemos, então, nos aproximar mais de uma teoria social da morte matada como forma de apurar melhor o que as circunstâncias do fazer morrer definem nos contextos que estudamos. Não se trata, entretanto, de reproduzir as classificações de Thomas e limitar o termo homicídio aos mesmos tipos de assassinatos que ele classifica. Seguiremos, dessa forma, utilizando os termos homicídio e assassinato de modo genérico e com significados equivalentes. Mas teremos a preocupação de buscar entender quais padrões políticos e sociais específicos essas mortes, extremamente frequentes e historicamente recorrentes, se vinculam. Ao estudarmos assassinatos na Baixada Fluminense, torna-se fundamental, assim, entender o modo pelo qual eles se articulam com o controle territorial e os modos de constituição dos poderes políticos municipais.

Na Baixada, um padrão de clientelismo homicida segue presente nas arenas municipais e se articula com outras práticas do fazer morrer que têm em comum com esse padrão a articulação com a operação de mercados ilegais. É recorrente que os parlamentares daquela região, em seus discursos, se remetam 
diretamente aos seus redutos eleitorais e nosso trabalho de campo apurou a permanência de um padrão que articula a formação de um reduto com desempenho do poder armado nessas localidades. Ainda é frequente, portanto, a atuação de políticos que emergiram a partir de sua própria atuação em grupos de extermínio ou milícias, bem como pelos benefícios de sua proximidade com esses grupos que definem, por exemplo, quem pode ou não fazer campanha nas áreas sob o seu controle. A permanência desse tipo de poder clientelista homicida se manifesta nas trajetórias de políticos como Zito, parlamentar e ex-prefeito de Caxias, sob o qual recaíram acusações (pelas quais não chegou a ser condenado) de envolvimento com execuções, ou de membros da família Abraão David em Nilópolis. Outro fato recente reforça a longevidade do modelo do político homicida encarnado de modo exemplar por Tenório Cavalcanti: seu neto, o político Fábio Tenório Cavalcanti Francesconi, presidente do diretório municipal do PTB em Duque de Caxias, foi nomeado no dia 16 de março de 2017, pelo prefeito da cidade, Washington Reis (PMDB), secretário especial de seu gabinete. Antes disso, o neto do Homem da Capa Preta ocupava o cargo de chefe de gabinete do Instituto de Pesos e Medidas do Rio de Janeiro (Ipem). Entre suas primeiras plataformas como secretário municipal, Fábio Tenório Cavalcanti defende a criação de um museu na cidade em memória de seu avô. Ele afirma: "O meu avô virou nome de rua em Pernambuco, Alagoas e São Paulo. Já em Caxias, não tem um beco sequer com o nome dele. No governo Zito, vendi a casa dele para a prefeitura transformar em museu, mas não chegou a sair do papel.". E ainda sugere que o museu poderia exibir alguns objetos de seu avô: "Seria bom mostrar alguns objetos dele. Só a capa preta que não coloco, é minha" ?

Esse padrão de articulação entre a política e a violência convive hoje com outras lógicas homicidas, como a presença do tráfico de drogas e suas disputas territoriais. Nossa pesquisa de campo sugere, entretanto, que é importante a atuação das milícias e dos grupos de extermínio para os homicídios na Baixada e esses grupos criminosos estão fortemente implicados no que chamamos aqui de clientelismo homicida. Não pretendemos fazer uma análise que apure qual o peso quantitativo da atuação de determinados grupos criminosos para o total das mortes por homicídio na Baixada. Procuramos, em vez disso, apurar nos materiais reunidos em nosso trabalho de campo como as narrativas dos nossos

\footnotetext{
${ }^{7}$ Ver a reportagem do Jornal Extra: http://extra.globo.com/noticias/extra-extra/neto-de-tenorio-cavalcanti-vira-secretarioem-caxias-quer-criar-museu-do-avo-21078593.html.
} 
informantes descrevem as dinâmicas da criminalidade violenta e suas percepções sobre os homicídios na região. Tendo em vista essas narrativas, a observação do contexto contemporâneo e seu histórico, foi possível apurar, como tentaremos mostrar ao longo deste estudo, que essa articulação entre controle territorial, política municipal e poder armado é a chave para se compreender as dinâmicas mais profundas e duradouras dos homicídios na Baixada. Foi possível perceber, em vista dessa perspectiva de análise, que os assassinatos se vinculam com determinado modo de produção da ordem. Foi frequente, assim, entre nossos informantes, a reprodução de narrativas nas quais é possível identificar o homicídio como um recurso naturalizado de imposição de uma ordem, sob o pretexto do combate ao crime. É essa lógica homicida que abriga descrições de um passado supostamente pacífico na Baixada, um passado no qual vigia a ordem imposta pelos grupos de extermínio e matadores locais. Tal como aparece na seguinte fala de um vereador de um município da Baixada que entrevistamos: "Quando você [, policial, vinha] trabalhar na Baixada Fluminense, [você constatava] que ali era uma casa de família! Não é mais! Isso era antigamente. Não é mais!". Essa caracterização da Baixada como "casa de família" se articula com uma moralidade que tem a eliminação do outro, do criminoso, através da atuação das forças locais ilegais, como um fator legítimo de produção da ordem.

Vamos a algumas cenas - do passado e do presente, coletadas em na bibliografia ou em nosso trabalho de campo - que formam mosaico desse contexto do qual pretendemos aqui traçar somente as linhas gerais.

\section{Cenas}

Cena 1

(...) O que ficou conhecido na imprensa como o caso da rua das Rosas [ocorrido em agosto de 1974], tornou-se, porém, uma espécie de ‘caso paradigmático' para a compreensão das ações dos grupos de extermínio praticadas pela polícia e noticiadas pelos jornais naquele período. Uma das vítimas era Pedro Paulo da Silva, 17 anos. A outra, nunca identificada, era um rapaz de 15 anos. Contra os dois foram disparados mais de 50 tiros de metralhadora; eles, porém, não tinham antecedentes criminais. Três dias depois do crime, quatro testemunhas eram apresentadas pelos jornais. Elas afirmaram que o carro dos assassinos era uma radiopatrulha da Polícia Militar de Nova Iguaçu. Raimunda do Espírito Santo era a mais determinada. Conhecia Pedro Paulo, que havia nascido e se criado em Vila de Cava, bairro de Nova Iguaçu onde estava localizada a rua das Rosas, e negava que ele fosse ladrão ou estivesse andando com más companhias. Sabia sim, que ele vendia giletes, pentes e balas no trem. Segundo Raimunda, eles gritavam pelo 'seu' Valdir (morador da casa vizinha à antiga barbearia onde estavam), pedindo 
pelo amor de Deus para não serem mortos. Os homens mandaram que eles ficassem de costas, com as mãos na cabeça, e depois vieram as rajadas de metralhadoras e tiros de outra arma. Dois dias depois, ao ser convocada pela delegacia de Nova Iguaçu para um depoimento sigiloso, Raimunda começou a mostrar-se reticente e temerosa de represálias. (...) Oito dias após o crime, uma nova versão surgiria. Os dois jovens teriam sido assassinados por engano numa vingança contra os assaltantes de um comerciante. Os assassinos seriam um sargento reformado da Marinha e dois soldados da Polícia Militar. (...) Para atenuar a culpabilidade dos dois soldados [, no julgamento,] ela [a polícia] pretendia apresentar os mortos como perigosos assaltantes. Desse modo, chegaram a falsificar ocorrências não apuradas para atribuir-lhes a autoria. (...) Ao final, o júri decidiu por quatro votos contra três pela absolvição dos acusados. (...) Cinco meses depois, o Tribunal de Justiça anularia a sentença, compreendendo que o júri fora realizado em condições anormais, com a sala da audiência tomada por uma assistência composta por 150 integrantes da Polícia Militar. Somente 4 anos depois do primeiro julgamento ocorreria o segundo. O conselho da sentença do Tribunal do Júri de Nova Iguaçu resolveu, no entanto, absolver novamente os acusados, pelos mesmos quatro votos contra três. (ALVES, 2003, pp. 131-134).

\section{Cena 2}

(...) Na noite de 26 de julho de 2014, aproveitando-se de uma festa, o CV iniciou sua guerra de invasão a Imbariê, Santa Lúcia e Parada Angélica em confronto direto com o TCP, que controlava a área até então. Neste conflito, evidenciou-se um padrão que já havia se espalhado por toda Baixada: uma alta vitimização sem divulgação pela mídia ou registro policial. No caso, informações que vinham das comunidades, onde os confrontos ocorriam, deram conta de mais de 20 pessoas mortas, em poucos dias. Para a polícia e jornais, não passaram de sete. Houve a denúncia, por parte da população, da existência de um cemitério clandestino na localidade. A polícia, no entanto, escavou à margem desta área, encontrando apenas dois corpos. A existência de cemitérios clandestinos na Baixada é antiga. A eles somam-se os rios, com destaque para o Sarapuí e Guandu, na prática de ocultamento de cadáveres. Nas obras do Arco Metropolitano, ossadas encontradas foram analisadas na esperança de serem achados [vestígios] arqueológicos de povos primitivos que ali habitaram. Algumas, contudo, não passaram de ossadas recentes (ALVES, 2016, p. 52).

\section{Cena 3}

$\mathrm{Na}$ educação infantil [crianças de cinco a seis anos], na sala em que eu trabalho (...) não tem uma brincadeira, não tem um brinquedo que não vire uma arma. (...) Eles começam, às vezes me assusta, assusta outras pessoas, porque eles acabam reproduzindo passos desse quadro violento. Eu tenho um aluno que, brincando com o outro, ele diz que o pai é miliciano e ele pegou o brinquedo [imitando uma arma] e falou: 'Agora eu vou ser o miliciano. Você é o bandido e eu vou te pegar'. (...) Aí ele botou o brinquedo na cabeça [do outro menino], e fingiu que puxou o gatilho, fez o som do tiro e o outro caiu. Eles interpretaram a cena e o outro caiu fingindo que estava morto. E as crianças que estavam também brincando, mas em outras coisas, começaram a gritar: 'Morreu! Morreu! Morreu!' E o outro [que fingia ser o miliciano] foi lá pegou a criança pelo pé, arrastou e falou: "Vou jogar dentro do Rio." A professora, depois de observar a brincadeira, chamou os alunos para conversar e problematizar a brincadeira. Aquele que dizia ser o miliciano, ouvia o que a professora dizia e só ria o tempo todo. "Teve um outro que eu pedi para guardar os brinquedos, ele falou que não ia guardar, eu insisti e ele olhou pra minha cara e disse: 'Vou encher sua cara de tiro.' (Trecho da entrevista de uma líder comunitária e professora da rede pública de educação de um município da Baixada)

O que essas três cenas vistas em conjunto nos sugerem? Em primeiro lugar, uma trajetória longeva dos assassinatos no cotidiano da região. Na primeira cena, temos um caso que se tornou emblemático 
sobre o modo de atuar dos grupos de extermínio, ainda no século passado. A participação de policiais nesses grupos, os assassinatos como uma forma de controle dos crimes contra o patrimônio, principalmente, aqueles perpetrados contra estabelecimentos do comércio local. Está aí um padrão consistente e duradouro do clientelismo homicida na Baixada: a associação ilegal entre agentes de segurança pública e o setor privado local. Além disso, essa primeira cena traz outro elemento de longa duração no que diz respeito a esse padrão ilegal de controle da "ordem": a condescendência e, muitas vezes, cumplicidade do sistema de justiça criminal em relação à atuação desses grupos. Esse último fator é também uma consequência das articulações entre esses padrões de poder e a política local. Na fronteira entre o legal e o ilegal, as instâncias de controle e garantia da legalidade acabam por se tornarem fiadoras dos assassinatos ilegais sob o pretexto do controle da criminalidade.

A comparação entre a primeira cena e as outras duas representa também uma distinção entre as ressonâncias desses padrões antigos e de longa duração e as mudanças correntes no contexto contemporâneo. De um lado, temos o câmbio de um padrão de extermínio mais exibicionista e expiatório para um modo de atuação baseado no assassinato seguido de ocultação de cadáver. Por outro lado, temos a entrada em cena das disputas das facções do tráfico de drogas no cenário dos vínculos entre assassinato e controle territorial. Esse novo ator, entretanto, compartilha do modus operandi da ocultação de cadáver, atualizando a prática dos cemitérios clandestinos na Baixada. Essa prática histórica de desova em rios e ocultação de corpos é um fator que alimenta grande desconfiança dos ativistas e moradores da Baixada em relação aos números oficiais sobre homicídios na região.

Na última cena, temos, talvez, a expressão mais profunda e acabada de que uma prática qualquer se encontra impregnada no cotidiano: quando se manifesta nas brincadeiras infantis. Nesse caso, podemos ver como rotineira e naturalizada a presença das milícias na Baixada, bem como a difusão e conhecimento coletivo de suas práticas: o assassinato como via de produção de uma "ordem", manifesta na expressão de que quem é morto é o "bandido", a ocultação de cadáver como procedimento. A banalidade do assassinato, a arma como instrumento de imposição de uma vontade também é fortemente expressa pelo menino que, contrariado, diz: "Vou encher sua cara de tiro". 


\section{O cotidiano das mortes}

O material das entrevistas que realizamos nos fornece um registro bastante rico do contexto vivido por nossos informantes acerca da criminalidade homicida. A partir desse conjunto de depoimentos, podemos compreender melhor o paradoxo entre a frequência e o caráter cotidiano dos homicídios na Baixada Fluminense e os silêncios acerca do tema que encontramos entre os agentes públicos. É possível extrair ainda percepções mais detalhadas sobre como ocorreram as reconfigurações da criminalidade violenta nos últimos anos, considerando, ainda, os depoimentos que estabelecem narrativas que têm o período posterior à expansão das UPPs na capital. Abordaremos, além disso, relatos acerca dos grupos criminosos presentes na Baixada, seus modos de atuação, e suas tensões e articulações com atores do poder público, possibilitando uma interpretação da violência letal intencional não como fenômeno difuso, mas como matéria prima para mercados que movimentam a circulação de outros bens políticos e patrimoniais.

Em relação a esse último aspecto, acreditamos que o mosaico dos depoimentos aqui coligidos permite identificar a existência de determinados lugares sociais para a violência letal intencional que resultam na operação de certos mercados. Ter o poder de matar significa participar da aquisição e acumulação de outros poderes e bens. Temos, assim, um conjunto de dinâmicas homicidas cuja causalidade não pode ser avaliada apenas a partir de categorias genéricas e isoladas: o racismo, as distâncias e hierarquias sociais, o preconceito de classe, a violência estatal são todos eles elementos que, seguramente, concorrem para as incidências de homicídios na região, mas nenhum deles isoladamente dá conta de fornecer uma síntese compreensiva das questões mais decisivas para a magnitude da letalidade intencional na Baixada. As noções jurídicas e criminológicas também não dão conta de fornecer um quadro compreensivo consistente desse tipo de violência. As próprias categorias de "homicídio" e "violência letal intencional" dão nome às resultantes de fenômenos de naturezas muito distintas - elas descrevem, por exemplo, tanto o caso de um pai que mata os próprios filhos quanto o desfecho de uma disputa territorial de grupos criminosos concorrentes. 
O que está em jogo é a tentativa de se identificarem os fatores responsáveis pelos padrões mais recorrentes no conjunto das mortes violentas intencionais na Baixada Fluminense. Pelos depoimentos recolhidos nas entrevistas, o elemento de síntese que identificamos como mais eficaz, do ponto de vista analítico, e mais coerente, do ponto de vista empírico, consiste na articulação entre os modos de operação dos mercados ilegais e suas fronteiras com os poderes constituídos no Estado. Temos, assim, um vetor que comporta: os confrontos nos quais figuram faccões, grupos criminosos e atores estatais; as redes ilegais de cooperação entre essas instâncias; e o clientelismo homicida, com o controle sobre um eleitorado e sobre os serviços e bens públicos a eles fornecidos. Todas essas dimensões têm como operação de base o cometimento de homicídios dolosos como ferramenta para a aquisição de bens políticos e patrimoniais.

Em contraste com as primeiras impressões do trabalho de campo junto aos gestores e agentes municipais, a continuidade da pesquisa trouxe outras percepções a serem consideradas em nossa análise. Ao aprofundarmos a entrada de nossa equipe no contexto de investigação, a partir das entrevistas e conversas com moradores, líderes comunitários, representantes da sociedade civil etc., chama a atenção o caráter cotidiano, quase banalizado, dos assassinatos na Baixada Fluminense. São comuns as falas que tratam dos homicídios dolosos como algo que acontece quase todo dia ou semana. Essas falas indicam que a banalidade é o operador que resolve o paradoxo da frequência exacerbada conjugada com baixa visibilidade. De tão recorrentes e cotidianas essas mortes deixam de chamar a atenção, deixam de ser investigadas, problematizadas, evitadas.

Diz-nos um ativista que entrevistamos: "Se você pergunta [ao jovem] se o bairro [que ele mora] é violento, o menino fala que não. Só que a maioria dos amigos já morreram, um monte de gente já foi assaltada, uma série de coisas violentas e o cara meio que vê isso como normal.”

Outro depoimento que obtivemos nas entrevistas fala não somente da recorrência dos casos, mas também do perfil mais comum nessas mortes cotidianas: os jovens:

Já perdemos muitos jovens aqui... muitos jovens. Perdemos agora um recentemente aqui [...] perdemos um outro ali a cem metros. [...] Já perdemos vários jovens aqui nas redondezas por 
balas perdidas, trocas de tiros com policiais, com traficantes... Isso aí é frequente, a violência é demais aqui na nossa região. Já perdemos muitos jovens, já perdemos até as contas. Finais de semana sempre um, mas um, mais dois [jovens assassinados]. (Líder comunitário).

Importante notar que nosso interlocutor está falando do contexto do local onde ele mora que se trata de uma área periférica do município. Ele se refere, portanto, a jovens, pobres e, provavelmente, de baixa escolaridade como personagens dessas mortes que ocorrem toda semana. Esse perfil é determinante também para a banalização das mortes. Trata-se de um grupo social que - a despeito de ser o público, em geral, em qualquer parte do mundo, mais vulnerável quando se trata de homicídios -, no Brasil, especificamente, está submetido a fortes estigmas. A população negra, jovem e moradora de áreas periféricas no Brasil é recorrentemente identificada com categorias de acusação. Essas narrativas estigmatizantes têm como foco semântico a criminalização desses grupos. São recorrentes nas reportagens dos grandes veículos de comunicação sobre eventos violentos envolvendo esse perfil social - sobretudo nos casos em que se trata de ocorrências nas quais as polícias são autoras de mortes ou ferimentos contra esses jovens - que se termine a notícia com a informação de que os personagens possuem "passagem pela polícia". Essa informação, em geral, é absolutamente irrelevante para a avaliação do caso específico que é narrado, mas esse tipo de recurso retórico parece ter o objetivo de atenuar o peso das violências sofridas pelos jovens ou de isentar de responsabilidades os autores dessas violências. Um policial civil que conhecemos ao longo de nossas atividades de pesquisa no campo da segurança pública, costuma contar uma história que é bastante ilustrativa dos mecanismos de criminalização e estigma que recaem sobre os jovens negros e moradores de periferias. Ele conta que, logo no início de sua carreira como policial civil, estava trabalhando no patrulhamento de um bairro da zona sul do Rio de Janeiro com outros dois colegas na viatura. Em determinada altura, avistaram dois jovens brancos e, provavelmente, moradores de uma área de classe média do bairro. Esses jovens pareciam estar fumando maconha. Os policiais pararam a viatura, abordaram os dois rapazes e constataram que realmente portavam um cigarro de maconha. A atitude dos policiais foi apreender a droga e passar um sermão nos dois: falaram como era negativo usar drogas, como isso poderia atrapalhar as vidas deles etc. Depois da bronca ridiculamente tutelar, os rapazes foram liberados. No mesmo dia, mais adiante na rota de patrulhamento dos policiais, eles passavam por uma rua de acesso a uma favela do bairro e identificaram outros dois jovens fumando um baseado. Dessa vez, os dois eram negros e, provavelmente, moradores da favela nas adjacências. A postura dos 
policiais foi completamente diversa da situação anterior. Insultos, agressões físicas, humilhações, ameaças compuseram o conjunto de ações dos policiais contra os dois usuários de maconha. Esse dois pesos e duas medidas, como dissemos, sintetizam as posturas recorrentes no Brasil na direção daqueles que são os principais atingidos pela violência letal intencional. A ação da polícia, no caso narrado, mas também em geral, é o reflexo de uma postura essencialmente violenta da população em relação a esse grupo social.

Vejamos outro depoimento do mesmo líder comunitário da citação anterior:

Tem as duas coisas. Têm pessoas que são envolvidos, outros que não são envolvidos. Têm as pessoas que estão passando na hora, que são os inocentes, que não têm nada a ver com o 'babado'. Às vezes a gente vê o que está acontecendo, lá embaixo, na cidade [do Rio de Janeiro], as pessoas no meio das balas cruzados, dos tiros cruzados e pega num inocente... a mesma coisa acontece aqui na Baixada. São pessoas que realmente estão envolvidas com o tráfico, outros não estão envolvidos e acabam perdendo a vida por causa de uma coisa que são tem nada a ver. E isso é o vem acontecendo frequentemente aqui na nossa região.

Temos nesse trecho um elemento importante para a compreensão dos significados presentes nas mortes dos jovens na Baixada: a figura do "envolvido". Essa categoria sintetiza a retórica que parece querer definir as mortes desses sujeitos como aceitáveis ou menos graves do que as mortes de pessoas “inocentes", assim como ocorre nas reportagens que se referem às fichas criminais dos personagens. Se recair sobre a pessoa assassinada o pertencimento à condição de "envolvido", sua morte se torna, retoricamente, uma consequência de suas próprias "escolhas" ou ações. Dispersam-se, portanto, as atenções sobre esses casos. Não são feitas investigações ou diligências adequadas. Há pouca repercussão jornalística. Os autores raramente são identificados. Se forem policiais, raramente são punidos ou investigados, se aceitando tacitamente as alegações de que o policial matou em defesa própria. As famílias dos mortos são ignoradas pelo Estado. Ao se mobilizarem para cobrar justiça por parte das autoridades, são ameaçadas e perseguidas, muitas vezes, pelos próprios autores das mortes de seus filhos e familiares que não são processados ou respondem aos processos em liberdade. Se o autor do crime é outro jovem também identificado como um "envolvido", também é baixa a sensibilidade social em relação a essas mortes, sob uma narrativa difusa que parece afirmar "eles que se matem por lá". Se o homicídio foi cometido por um miliciano ou grupo de extermínio, o silêncio é decorrente do medo. Quando não se trata de medo, está em jogo certo acordo moral com os homicidas: 
eles estariam botando ordem na área, fazendo uma "limpeza", como aparece num depoimento que citamos no capítulo anterior, matando quem deve morrer. Às famílias, com frequência, se recusa inclusive o acesso aos corpos pelo uso de técnicas de ocultação de cadáver como as desovas em rios da região. Nosso informante citado acima, ainda que não compartilhe dessas narrativas impregnadas por moralidades que tornam as mortes de jovens negros e pobres irrelevantes, ou mesmo necessárias, reproduz as categorias de estigma e acusação em sua fala.

Em todas as hipóteses referidas acima, a categoria de "envolvido" serve como um neutralizante retórico do curso social dessas mortes. Vistos como pessoas que podem ou devem morrer, esses jovens passam a figurar como aspecto central de um mercado homicida. Os discursos estigmatizantes operam, em primeiro lugar, uma redução dessas pessoas à condição de "coisa”. Há, em segundo lugar, um mercado de aquisição de poderes pelo exercício do poder de matar. Esse poder é o elemento que lastreia a conquista de um território e, logo de um mercado de bens e serviços ilegais, e de votos. Reduzidos social e retoricamente a meras quantidades, a morte desses jovens passa a ser o aspecto central de um mercado homicida. Esse mercado é o elemento estruturante de uma perversão política muito comum no Brasil, histórica e contemporaneamente: uma moralidade que prioriza o patrimônio em detrimento da vida como valores. As mortes cotidianas e banalizadas de jovens opera como meio para o controle, manutenção e aquisição de mercados que têm como fim último a produção de ganhos financeiros e patrimoniais para seus gestores e operadores. Esse é o horizonte de expectativas dos traficantes de drogas, dos milicianos, dos policiais corruptos, dos membros dos grupos de extermínio, dos políticos cujas carreiras decorrem dos votos conquistados pelo controle territorial armado de determinadas áreas das cidades, todos eles personagens centrais dos conflitos que concorrem para a alta incidência de mortes na Baixada Fluminense e outras regiões brasileiras.

Uma ativista que entrevistamos fala de uma dinâmica que é bem expressiva da redução do valor da vida em vista da aquisição de mercadorias, mesmo no caso de bens de pouco valor.

\footnotetext{
Há anos atrás... Porque aqui matava criança de doze, treze, catorze anos. (...) Final de semana era dia de morrer sim. O moleque entrava na boca, na sexta, muitas vezes no sábado e no domingo ele dava a volta na boca, ele morria. Até na mão de um colega igual a ele, do tamanhozinho dele. É o quê? A ansiedade. Comprava sapatos de marca, comprava, aquela
} 
vontade de ter, aí não tinha responsabilidade nenhuma, ia lá e comprava. Você sabia que ele tinha que prestar conta. Então, houve muito isso. Não só aqui como em todas as favelas. [...]. A Zona Sul, Copacabana, Ipanema, está cheio disso. Mas eu falo do que eu vivi aqui.

É importante notar a seguinte frase desse trecho: "Final de semana era dia de morrer sim." Ela expressa a incidência das mortes não como algo episódico, mas quase sistêmico, uma consequência do modo de operação de um negócio, a "boca". Quando fala do elemento desencadeador do conflito que resulta nessas mortes recorrentes, ela às associa a uma "ansiedade" pela aquisição de mercadorias como um "sapato de marca", uma "vontade de ter". O sujeito reificado, reduzido à quantidade, desprovido de atributos socialmente valorizados, é sugado pela roda viva do mundo das coisas.

Ainda no que se refere às consequências retóricas e morais associadas à noção de "envolvido", um de nossos entrevistados, ator da sociedade civil organizada, fala de como perdeu três sobrinhos vítimas de homicídio:

Três sobrinhos meus já foram assassinados. (...) Envolvidos com drogas. Um sobrinho meu, simplesmente, estava olhando a arma que o menino estava mostrando para ele. Quando a polícia chegou e viu ele, e identificou ele com a arma na mão. Ele nunca tinha usado uma arma, ficou escondido atrás do caminhão. Mataram ele. (...) Agora eu pergunto: a culpa é do policial? Ele tinha 17 anos. A culpa é do policial? Não. Por quê? [O policial pensa:] 'Antes de a minha mãe chorar, chora a mãe dele. Porque ele está com a arma na mão. Ele vai atirar em mim.'

Esse personagem descreve uma cena que possui um caráter trágico, insolúvel. Seu sobrinho foi morto injustamente. Já o policial que o matou tampouco é culpado do assassinato que cometeu. Em seu discurso, a ação do policial se justifica pela autodefesa: "Antes da minha mãe chorar, chora a mãe dele". Essa sentença indica o quão recorrente são os homicídios no cotidiano das operações do crime e seus contatos com as instâncias legais e ilegais presentes no poder público. Elemento de baixo custo no conflito entre forças do crime e do Estado, matar e morrer são resultados frequentes nessas relações. Ao reconhecer o ponto de vista do policial como compreensível e legítimo, nosso informante não está reproduzindo a lógica do baixo valor da vida dos jovens negros e periféricos na Baixada. Ele está, na verdade, reconhecendo que as origens do problema são mais amplas do que a circunstância concreta que provoca aquele encontro no qual matar ou morrer são os resultados iminentes e inevitáveis. 
Esses enredos marcados pelos homicídios como desfecho não se restringem aos contextos e modos de operação do tráfico de drogas. Uma de nossas entrevistadas, membro do movimento negro, perguntada se já teve algum caso que resultou em morte por causa da milícia que controla a área em que ela vive, responde: "Sempre tem. Quase toda semana". Mas ela diz que essas mortes nem sempre são visíveis, seguindo o padrão retratado por Cano e Duarte no livro "No Sapatinho" . Nesse livro, eles descrevem as mudanças nos modos de operação das milícias destacando que nos últimos anos, principalmente depois do contexto da CPI que resultou na prisão de alguns de seus principais líderes, esses grupos deixaram de lado as execuções públicas e expiatórias que lhes eram características e passaram a adotar um modo de atuação mais discreto, voltado para a ocultação dos cadáveres em seu padrão homicida.

Outra ativista da Baixada que entrevistamos fala da recorrência dos homicídios como algo característico tanto de tráfico quanto da milícia:

A minha área é dominada pelo tráfico e agora pela milícia. Então, assassinatos - homicídios - e tiroteios é o pão de cada dia. Não tem semana onde não tenha toque de recolher. Alguém desses grupos de traficantes ou da milícia morre. Então, eles obrigam o comércio a fechar as portas. E para entrar nessas áreas você tem que entrar com as luzes do carro apagadas, os vidros abertos e só a luz interna acesa. E, se entra um carro que não é da área, é barrado pelo tráfico, principalmente, tráfico.

Já outro ativista que entrevistamos compara a alta frequência de homicídios na sua região com a magnitude dos dados oficiais:

[...] o que mais me abala é a questão dos homicídios. Por exemplo, na semana passada, executaram um cara próximo à minha casa. (...) Eu não ouvi os tiros porque eu estava vendo alguma coisa na televisão, mas eu vi que meu cachorro estava latindo muito. Aconteceu alguma coisa. Depois eu vendo na página [da cidade, na internet], a quatrocentos metros da minha casa, estava um rapaz de vinte e dois anos, caído lá, foi assassinado. A gente não sabe o que aconteceu. Foi execução, com vários tiros. Então, isso aí me abala. A quantidade de execuções sem investigação, sem nada, e que ocorrem diariamente. A gente não vê diariamente, porque acontecem em pontos distintos do município, mas a gente sabe que todo dia tem um caso na Baixada. E eu acho interessante - não no sentido de legal, mas no sentido de comparar os dados - é que às vezes parece que os números do ISP são inferiores àquilo que a gente vê de fato. Porque a gente fica sabendo de vários casos e aí quando a gente vai ver os casos registrados, a gente não consegue ver [a mesma proporção].

Para ele, o número elevado de homicídios computados pelo ISP não é compatível com a quantidade que ele observa no cotidiano, que seria maior. Em todas as falas de nossos entrevistados, de toda forma, a

\footnotetext{
${ }^{8}$ Cano \& Duarte (2012).
} 
violência letal intencional é prioritariamente decorrente das operações e conflitos entre grupos criminosos - tráfico, milícias e grupos de extermínio -, bem como de suas relações e confrontos com as forças policiais e outros poderes constituídos na esfera governamental.

Será importante para a análise aqui proposta não somente essa constatação, mas a forma pela qual nossos informantes valoram e descrevem os modos de atuação de cada um desses grupos e também os expedientes discursivos aos quais recorrem para falarem do cenário da violência na Baixada Fluminense.

\section{Os homicídios e outras formas de criminalidade violenta: a vida e o patrimônio}

Quando se trata, especificamente, dos homicídios cometidos por esses grupos criminosos, um padrão recorrente é a ocultação dos cadáveres. Isso reforça a tônica dos silêncios que giram em torno desse tipo de violência tão presente na região. É, portanto, importante que haja um conhecimento difuso dessas práticas, mas seus vestígios são apagados como forma de impedir as possibilidades de apuração desses crimes. Isso indica, por um lado, uma mudança nos padrões de impunidade dos autores, que seguem sendo publicamente reconhecidos, mas, por outro lado, atesta a adoção de um novo estilo de prática homicida que é essencial para a manutenção das mortes intencionais como elemento central das práticas criminosas.

Uma ativista local que entrevistamos define da seguinte forma essas práticas:

O problema aqui é que a maioria dos homicídios não entra nas estatísticas porque eles assassinam as pessoas e os corpos desaparecem. Até se fala de que esses corpos são utilizados para o tráfico de órgãos. Isso é o que se comenta. Eu não tenho provas. Mas uma família aqui, eles estavam contando pra gente que o rapaz estava envolvido com o tráfico. Depois ele conseguiu um trabalho. E ele estava celebrando [por ter conseguido o trabalho], em um bar, o primeiro salário dele e desapareceu. A família começou a procurar e recebeu uma mensagem de que se eles continuassem com a busca a família toda ia desaparecer. E não encontraram o corpo. Outro relato é de um pai que só pôde enterrar a cabeça do filho porque o resto do corpo desapareceu.

Já um representante de um grande sindicato patronal, muito ativo nos espaços de participação da sociedade civil na Baixada, comenta um vasto repertório de crimes que acometem a região nos dias de 
hoje, mas quando indagado sobre os homicídios, só admite a ocorrência desses delitos violentos associados ao latrocínio:

\footnotetext{
Olha, homicídio... homicídio muito em função do latrocínio. Latrocínio sim. Homicídios pura a simplesmente, eu acho que tem diminuído um pouco, mas eu não tenho a estatística porque eu não pude ainda sentar com o delegado. [...] Nós tivemos sim alguns homicídios nos últimos três meses, mas em função da guerra do tráfico, entre as facções.
}

Logo em seguida a essa declaração, único momento em que falou de homicídios em uma entrevista de quase duas horas, ele muda de tópico e passa a tecer comentários sobre a estrutura das delegacias da região. Esse personagem, a cujo depoimento para a pesquisa voltaremos a nos referir em outros pontos desta análise, alega ter vasto acesso a informações relacionadas aos crimes na região. Sua fala é repleta de detalhes sobe como os grupos criminosos atuam na Baixada. Ele retrata o contexto narrado como uma "verdadeira guerra", mas se limita a indicar como elementos desse conflito os crimes contra o patrimônio e, quando é instado a comentar a respeito dos homicídios, os vincula diretamente ao latrocínio e restringe suas ocorrências aos eventos relacionados às disputas entre as facções do tráfico. Não foi incomum encontrarmos essa postura tanto entre gestores municipais quanto entre representantes da sociedade civil que parecem participar intensamente das ações do poder público na região. Esse padrão discursivo presente nesses dois perfis de entrevistados é mais nítido naqueles que parecem possuir vínculos com a política institucional local. Interpretamos essa postura como certa adesão moral às práticas homicidas, típicas dos grupos de extermínio, que operam um mercado no qual o patrimônio é considerado um valor superior à vida: isso quando se trata de descrever o valor dos bens morais e materiais e daqueles que potencialmente atentariam contra esses bens. Ao que parece, essa retórica é fundamental para a exclusão das execuções rotineiras nos mercados ilegais, como retratamos no início deste capítulo, do repertório das preocupações públicas acerca da segurança pública.

Outro entrevistado, gestor municipal de uma prefeitura da Baixada, atuando especificamente no campo da prevenção da violência, nos traça um panorama bastante amplo das reconfigurações recentes da criminalidade. 
cá. E isso seria uma das explicações do aumento da violência, sobretudo, da violência letal. Isso tem a ver com o fato de que os índices de latrocínio são muito baixos. Nós tivemos anos em que só houve um latrocínio. Agora, os [índices] de execução são muito altos. 0 que a gente não consegue perceber seria as motivações de autoria. A gente não tem esse feedback. Pelas narrativas do Conselho [Municipal de Segurança Pública], (...) são duas autorias específicas tirando casos, por exemplo, de violência doméstica que também é alta etc. (...) A gente não sabe dizer quais são os grupos concorrentes. O que nós sabemos é que a atuação de grupos de extermínio é muito forte, historicamente. A gente não sabe se eles estão se profissionalizando e se convertendo em milícia. A gente não tem essa informação, mas é possível, é bem possível. E a gente não sabe dizer a penetração real do tráfico de drogas aqui. Que houve um aumento, houve. Porque os delegados que participaram do [conselho municipal], que iam eventualmente às reuniões e os policiais civis, e também o mapa da violência mostra isso, que a apreensão de entorpecentes é muito grande. Então, houve um aumento da circulação de drogas. E também houve um aumento na apreensão de crianças e adolescentes. Há sim testemunhos de circulação de traficantes armados. (...) A gente não sabe exatamente a que ponto a milícia explora o tráfico de drogas, de que maneira ela está estruturada. Uma outra coisa que chamou a atenção, mas que foi combatido pela Polícia Civil aqui, eram esses escritórios de empréstimos [(agiotagem)]. Era muito forte na Baixada Fluminense, principalmente, em Nova Iguaçu. (...) E isso foi sendo estourado [pela PCERJ] porque isso era um braço financeiro da milícia. Agora, quando a gente fala em milícia, a gente tem que entender que, pela nossa percepção, que não se trata de um grupo visível, muito claro e organizado, como, por exemplo, uma organização política atuando no Legislativo. Me parece, ainda, que eles têm resquícios de uma atuação ainda muito semelhante à dos grupos de extermínio que atuam aqui na Baixada desde a década de 1940.

É importante notar que de modo distinto do discurso do representante do sindicado patronal referido anteriormente, os casos de latrocínio são baixos na região. Ele fala, ainda, de um padrão já conhecido na atuação das milícias: o fato de operarem o mercado de venda de drogas ilícitas e as práticas de agiotagem como mais um fator de sustentação econômica das milícias.

Ainda que o tráfico recorra às execuções sumárias com ocultação de cadáveres, esse padrão parece ser mais característico das milícias e dos grupos de extermínio. Uma de nossas entrevistadas, que vive numa área que já foi dominada por traficantes e agora é comandada por uma milícia, relatou que o tráfico desova corpos nos rios, mas costuma autorizar as famílias a procurarem esses corpos depois que as cenas das execuções já estão descaracterizadas. Uma ativista da Baixada no seu depoimento define as execuções com ocultação de cadáver como algo característico especificamente das milícias: "Falam que a milícia é a responsável por essa questão dos homicídios com desaparecimento dos corpos."

O personagem que talvez melhor tenha sintetizado a equação de que os crimes contra a vida são uma forma de controle ilegal das ocorrências de delitos contra o patrimônio foi um vereador que entrevistamos que é policial reformado e comerciante: 
O índice de homicídios melhorou muito, até porque tem pouco miliciano hoje na cidade. Quando tinha muito miliciano, tinha muito, muito... tinha mais homicídio, mas tinha menos bandido. Hoje tem muito bandido e pouco homicídio. Hoje tem muito assalto. $\mathrm{O}$ índice de homicídio é bem menor do que antes. Assim, pelo o que a gente sente nas ruas. Dificilmente a gente vê pessoas mortas, como antigamente você via três ali, dois ali. Hoje você não vê isso não. Você vê muito é assalto.

Ao que parece, essa fala opera uma indistinção entre as figuras do miliciano e do matador do grupo de extermínio. Seu discurso descreve explicitamente o uso do homicídio como uma via de controle de crimes como os assaltos. Interessante notar também que ele distingue as figuras do "miliciano" e do "bandido". No seu relato para a pesquisa, os crimes como os assaltos são narrados como o aspecto mais preocupante do cenário de violência na Baixada. Ele parece apresentar certa indiferença em relação aos homicídios e no trecho acima não esboçou nenhum sinal de desaprovação do homicídio como forma de controle dos crimes contra o patrimônio. Apesar de descrever o cenário dos homicídios hoje como mais controlado do que no passado, seu discurso narra, o tempo todo, uma Baixada nos dias atuais como mais violenta do que no passado.

Um guarda municipal, sem definir se fala de uma milícia ou de um grupo de extermínio, narra o uso do homicídio como um elemento de imposição de uma "ordem”. Às ameaças de que se "bagunce o coreto", a resposta desses grupos é uma "limpeza da área":

[No bairro X] tem o pessoal que não deixa bagunçar o coreto. Tem uma turma ali que a gente sabe que eles não deixam. Então, vira e mexe quando aparece um ou outro ali, a gente sabe que pode ter, vindo dali daquele grupo, meio que uma limpeza na área.

O modo de execução dessas "limpezas" segue a lógica daquilo que tem que tomar conhecimento público - para que saibam que tem alguém que faz essa "limpeza" - mas que deve acontecer com uma alta dose de discrição. Esse tipo de ordenamento ilegal dos territórios, muitas vezes, funciona sob a lógica de que é necessário que todos saibam que algum chefete é o responsável por essas "limpezas", porque ele é reconhecido como o "dono da área", mas que a ele não possam ser imputadas nenhuma morte por ele cometida ou perpetrada em seu nome. Na prática, todos sabem que aquele personagem é um matador, mas sua imagem pública é a do benfeitor local. Esses chefetes, de modo recorrente, constroem carreiras políticas que tem por base o controle do eleitorado local. Esse arranjo configura especificamente o que chamamos aqui de clientelismo homicida. 


\section{CONCLUSÃO}

Sintetizando-se as tendências gerais das mortes cometidas pelos grupos criminosos da Baixada Fluminense, a partir dos relatos de nossos entrevistados, é possível perceber que:

(i) As mortes decorrentes das circunstâncias em que os traficantes são autores estão mais frequentemente referidas em casos de confronto por disputas territoriais, bem como com a polícia; além disso, há casos relatados de execuções por parte do tráfico como retaliação a dívidas adquiridas com a "boca" e outros acertos de contas.

(ii) Os homicídios cometidos pelas milícias compartilham da lógica do que estamos chamando de clientelismo homicida, com a operação de mercados ilegais e com o controle de eleitorados que garantem a articulação com os poderes políticos estatais; essas mortes são narradas como execuções que estão associadas ao uso de métodos de ocultação de cadáveres. Como parte da lucrativa rede de serviços ilegais operados pelas milícias, identificamos também as execuções associadas à noção de "limpeza", ou seja, assassinatos de pessoas que representem alguma desordem local do ponto de vista dos clientes dos serviços milicianos, como alguns comerciantes.

O padrão homicida na Baixada está articulado à operação dos mercados ilegais nos quais o ato de matar opera como fator chave. Poder matar é adquirir credenciais nos mercados ilegais de bens financeiros e políticos.

Se os mercados ilegais já vinham, há muito, sendo apontados como correlatos às dinâmicas do homicídio no Brasil, o contexto da Baixada exemplifica processos nos quais esses mercados estão em relação com a política e com o Estado. Vimos, assim, como o uso excessivo da força, o poder de matar, por parte dos policiais é manejado como uma ferramenta para a aquisição de ganhos financeiros. Já no que diz respeito à fronteira com a política, explicitamos uma rede de poderes que tem, na base, o controle de territórios e eleitorados e a exploração criminosa serviços públicos e privados e, na ponta, carreiras políticas em cargos eletivos e de confiança. É nessa fronteira com a política e seu vínculo com os mercados criminosos que se configura uma modalidade de letalidade violenta que chamamos de clientelismo homicida. 
As práticas homicidas desses arranjos de poder são definidas por três métodos prioritários: o confronto, a execução e a ocultação de cadáver. Nas disputas por território, predominam o confronto. Nos acertos de contas, nas "limpezas de área", nas disputas por liderança, nas demonstrações de poder, nas punições por comportamentos e práticas "desviantes", as execuções, seguidas da ocultação do cadáver, são os métodos homicidas prioritários. O levantamento de notícias de jornais apresentado no último capítulo, sugere que o padrão mais recorrente de homicídios na Baixada se refere às execuções, sendo os confrontos mais ocasionais e fortuitos. Nos casos em que nossos entrevistados se referiram às mortes que ocorrem cotidianamente, a maior parte das narrativas descreve casos de execuções.

Os personagens que operam esse mercado homicida são facções do tráfico de drogas, grupos de extermínio, milícias, polícias e políticos. Todos eles são operadores dos métodos e das circunstâncias resumidas acima. Os laços desses mercados criminosos com a política e com o Estado sugerem que determinadas contradições do próprio Sistema de Justiça Criminal e dos poderes municipais operam, de certa forma, como uma retaguarda: seja na fragilidade da tutela da segurança como direito, seja na complacência na fiscalização e na punição das práticas homicidas articuladas ao poder.

\section{REFERÊNCIAS}

ARENDT, Hannah. Compreender: formação, exílio, totalitarismo (ensaios). São Paulo: Companhia das Letras, 2008.

ALVES, José Claudio Souza. Dos barões ao extermínio; uma história da violência na Baixada Fluminense. Duque de Caxias: APPH; CLIO, 2003.

ALVES, José Claudio Souza. Casos da Região. In: FÓRUM GRITA BAIXADA. Um Brasil dentro do Brasil pede Socorro: relatório-denúncia sobre o descaso estatal com a vida humana na Baixada Fluminense e possíveis soluções urgentes. Nova Iguaçu: Fórum Grita Baixada, 2016.

CANO, I; BORGES, D.; RIBEIRO, E., Os donos do morro. Rio de Janeiro: LAV/UERJ, 2014.

CARVALHO, José Murilo de.. Mandonismo, coronelismo, clientelismo: uma discussão conceitual. Dados, Rio de janeiro, v. 40, n. 2, 1997.

LEAL, Victor Nunes. Coronelismo, enxada e voto. São Paulo: Alfa-Omega, 1976.

SILVA, Hélio R. S.. Linhas de Auxílio: estigma de localização. Comunicações do ISER. Rio de Janeiro, n. 66, ano 31, 2012.

THOMAS, Louis-Vicent. Antropología de La muerte. México: FCE, 1983. 